\title{
Performances of bottom dwelling carpsin polyculture ponds under drought prone Barind area of Bangladesh
}

\begin{abstract}
Selection of appropriate bottom dwelling species is considered important to address the problem of increased temperature and reduced culture period for carp polyculture in ponds under drought prone Barind area (with characteristic soil and water quality) in Bangladesh. This experiment evaluated the performances of bottom feeding carps for polyculture ponds in Tanoreupazila of Rajshahi district, Bangladesh. Three different combinations of bottom feeding carps were tested under three treatments (T1: polyculture involving Cyprinuscarpio as bottom dwelling carp; T2: polyculture involving Cirrhinus mrigala as bottom dwelling carp; and T3: polyculture involving Labeocalbasu as bottom dwelling carp).Each treatment had three replications. Fish growing period (July-December), mean weight $(100 \pm 0.4 \mathrm{~g})$ and density of the stocked species (Catla catla-741/ha, Hypopthalmichthys molitrix-1,976/ ha, Aristichth is nobilis-741/ha, Labeo rohita-1,976/ha and Cyprinus carpio/ Cirrhinus mrigala/Labeo calbasu -1,976/ha; all species-7,410/ha), lime and ash treatment, fertilization and supplementary feeding were same for all treatments. Water quality parameters were monitored monthly and mean values were found within the suitable range. Treatment T1 (with Cirrhinus carpio as bottom dwelling carp) varied more significantly $(\mathrm{P}<0.05)$ than other treatments for the mean values of growth (Final weight, weight gain, specific growth rate and survival rate), yield and net benefit.
\end{abstract}

Keywords: bottom feeder, carp polyculture, drought
Volume 7 Issue I - 2018

\author{
Mohammad Golam Sarowar Talukder, \\ AkhtarHossain, Mohsin ABM, Rafiqual Islam \\ Khan \\ Department of Fisheries, University of Rajshahi, Bangladesh
}

Correspondence: Mohammad Golam Sarowar Talukder, Department of Fisheries, University of Rajshahi, Bangladesh, Tel +937303591 16, Email sarowar1967@gmail.com

Received: January 6, 2018 | Published: January 17, 2018

\section{Introduction}

Importance of pond based carp polyculture as a popular technique for fish production in Bangladesh is well documented. ${ }^{1}$ It has further potentials to improve the livelihood of the poor and marginal peoples. ${ }^{2}$ Potentials of pond based fish production towards livelihood improvement are also explored well by Hossain et al. ${ }^{3}$ for Barind area having characteristic soil-water qualities like lower $\mathrm{pH}$ and organic matter content in soil along with lower alkalinity and higher turbidity level in pond water. ${ }^{4}$ Apart from these potentials of pond polyculture and constraints for fish production associated with soil-water qualities, promotion of aquaculture is found to be affected by climate change aspects. Studies indicate that climate change may result in decline of groundwater level ${ }^{5}$ and thus remodelling of carp polyculture is felt necessary in terms of insufficient water level in ponds under drought prone area. Fish production in polyculture is largely affected by species combination, stocking density, pond fertilization, supplementary feeds as well as ecological conditions. Stocking of comparatively larger size of carps can solve the problem of fish production for lower water column in polyculture ponds under drought prone area. ${ }^{2}$ However all species do not play equal role in terms of water quality and fish production. The knowledge of fish-fish and fish-environment relationships enables choosing adequate combinations of fish species, stocking rates, input types and rates, and other management decisions according to the specific local conditions; climate, quality of water supply and pond fertility, availability of fish fry and fingerlings, availability of feeds and fertilizers, and market requirements. ${ }^{6}$ Polyculture is the system in which fast growing compatible species of different feeding habits are stocked in different proportions in the same ponds Chakraborty et al., 2005. The bottom dwelling carps help re-suspension of bottom nutrients to water while stirring the bottom mud in search of food. Such an exercise of bottom dwellers also aerates the bottom sediment. Techniques to mitigate the low alkalinity and high turbidity problems are found to be addressed well but guidelines are not found for selecting appropriate bottom dwelling species for profitable carp polyculture in ponds under drought prone area. This study evaluated the performances of bottom dwelling species in carp polyculture ponds under Barind area of northern Bangladesh. The specific objectives of this study were to monitor the water quality and fish growth; to evaluate the yield and economics of carp polyculture; and thereby to recommend best performing species combination for profitable carp polyculture in ponds under drought prone Barind area.

\section{Materials and Methods}

\section{Study duration and location}

The study was conducted in nine ponds (mean water area of $0.025 \pm 0.003$ ha and depth of $1.66 \pm 0.096 \mathrm{~m}$ ) for a period of six months (July to December) in Rajshahi district, Bangladesh $\left(24.3545^{\circ} \mathrm{N}\right.$, $088.3200^{\circ} \mathrm{E}$ to $24.3553^{\circ} \mathrm{N}, 088.3222^{\circ} \mathrm{E}$; elevation: 21 to $23 \mathrm{~m}$ ). All the ponds were rain-fed and well exposed to sunlight of average 8 hours per day.

\section{Experimental design}

Randomized Completely Block Design (RCBD) was followed for the present experiment with three treatments of combinations of bottom dwelling species ( $\mathrm{T}_{1}$ : polyculture involving Cyprinuscarpio as bottom dwelling carp; $\mathrm{T}_{2}$ : polyculture involving Cirrhinusmrigala as bottom dwelling carp; and $\mathrm{T}_{3}$ : polyculture involving Labeocalbasuas bottom dwelling carp). Each treatment had three replications. Stocking density (Catla catla-741/ha, Hypopthalmichthys molitrix-1,976/ha, Aristichthis nobilis-741/ha, Labeo rohita-1,976/ ha and Cyprinuscarpio/ Cirrhinusmrigala/Labeocalbasu -1,976/ha; 
all species-7,410/ha) and mean individual stocking weight of fish $(100 \pm 0.4 \mathrm{~g})$ were same for all treatments.

\section{Pond management}

Weeding was done manually and predatory fish and other unwanted species were removed through repeated netting. In order to maintain good water quality, liming $(\mathrm{CaO} @ 750 \mathrm{~kg} / \mathrm{ha}$ as basal dose and $125 \mathrm{~kg} / \mathrm{ha} / \mathrm{month}$ as periodic dose) with ash $(2500 \mathrm{~kg} / \mathrm{ha} /$ month) treatment was followed after Hossain (2011) for all the ponds. To enhance the natural feed production in the experimental ponds, fertilization was also done by cow dung (Basal dose: $2500 \mathrm{~kg} / \mathrm{ha}$; periodic dose: $2500 \mathrm{~kg} / \mathrm{ha} /$ month), urea (Basal dose: $50 \mathrm{~kg} / \mathrm{ha}$; periodic dose: $50 \mathrm{~kg} / \mathrm{ha} /$ month) and TSP, Triple Super Phosphate (Basal dose: $50 \mathrm{~kg} / \mathrm{ha}$; periodic dose: $25 \mathrm{~kg} / \mathrm{ha} / \mathrm{month}$ ). Basal fertilization was done after three days of liming. Selected species of carp fingerlings were purchased from a private nursery and stocked in the morning (Table 1) (Table 2). Home-made feed prepared with rice bran $(50 \%)$ and mustered oil cake $(50 \%)$ was administered into the ponds at $4 \%$ of fish body weight (6\% for July-August, $5 \%$ for September-October, $3 \%$ for November and $2 \%$ for December) once a day between 10:00 and 11:00 AM using feeding tray. Quantity of feed was adjusted every month according to total biomass of fish obtained from the sampling.

\section{Monitoring of water quality parameters}

Water quality parameters like temperature, transparency, dissolved oxygen (DO), $\mathrm{pH}$, and alkalinity were monitored monthly between 09:00 and 10:00 AM for the present study. Water temperature was recorded with the help of a Celsius thermometer, transparency was measured by a Secchi disk. Dissolved oxygen (DO), $\mathrm{pH}$ and alkalinity were determined by the help of a HACH kit (FF-2, USA).

Table I Experimental layout for carp polyculture in ponds under different treatments.

\begin{tabular}{|c|c|c|c|c|c|c|c|c|c|}
\hline \multirow{3}{*}{$\begin{array}{l}\text { Parameters } \\
\text { Replications }\end{array}$} & \multicolumn{9}{|c|}{ Treatments and Replications } \\
\hline & \multicolumn{3}{|c|}{$\begin{array}{l}T_{1}: \text { Ponds Stocked } C \text {. carpio as } \\
\text { bottom feeder) }\end{array}$} & \multicolumn{3}{|c|}{$\begin{array}{l}\mathrm{T}_{2}: \text { Ponds stocked with } C \text {. mrigala } \\
\text { as bottom feeder }\end{array}$} & \multicolumn{3}{|c|}{$\begin{array}{l}T_{3}: \text { Ponds stocked with } L \text {. calbasu } \\
\text { as bottom feeder }\end{array}$} \\
\hline & $T_{1} R_{1}$ & $T_{1} R_{2}$ & $T_{1} R_{3}$ & $T_{2} R_{1}$ & $\mathrm{~T}_{2} \mathrm{R}_{2}$ & $\mathrm{~T}_{2} \mathrm{R}_{3}$ & $T_{3} R_{1}$ & $T_{3} R_{2}$ & $\mathrm{~T}_{3} \mathrm{R}_{3}$ \\
\hline Pond area (ha) & 0.022 & 0.025 & 0.021 & 0.027 & 0.025 & 0.030 & 0.025 & 0.023 & 0.028 \\
\hline Pond depth (m) & 1.60 & 1.55 & 1.65 & 1.80 & 1.73 & 1.68 & 1.50 & 1.65 & 1.75 \\
\hline $\begin{array}{l}\text { Total fish } \\
\text { stocked }\end{array}$ & 163 & 185 & 156 & 200 & 185 & 222 & 185 & 170 & 207 \\
\hline
\end{tabular}

Table 2 Variations in the mean values of water quality parameters under different treatments during the study period.

\begin{tabular}{llllll}
\hline \multirow{2}{*}{ Parameters } & \multicolumn{3}{c}{ Treatments } & F value & P value \\
\cline { 2 - 5 } Water temperature $\left({ }^{\circ} \mathrm{C}\right)$ & $\mathbf{T}_{1}$ & $\mathbf{T}_{2}$ & $\mathbf{T}_{3}$ & & \\
Dissolved oxygen $\left(\mathrm{mgL} \mathrm{L}^{-1}\right)$ & $27.60 \pm 0.99^{\mathrm{a}}$ & $27.31 \pm 1.04^{\mathrm{a}}$ & $27.19 \pm 1.00^{\mathrm{a}}$ & 0.042 & 0.959 \\
Turbidity $(\mathrm{cm})$ & $6.76 \pm 0.23^{\mathrm{a}}$ & $6.74 \pm 0.22^{\mathrm{a}}$ & $6.71 \pm 0.24^{\mathrm{a}}$ & 0,011 & 0.990 \\
$\mathrm{PH}$ & $28.81 \pm 0.45^{\mathrm{a}}$ & $28.62 \pm 0.59^{\mathrm{a}}$ & $28.57 \pm 0.55^{\mathrm{a}}$ & 0.056 & 0.945 \\
Alkalinity $\left(\mathrm{mgL}^{-1}\right)$ & $7.12 \pm 0.08^{\mathrm{a}}$ & $7.10 \pm 0.08^{\mathrm{a}}$ & $7.19 \pm 0.07^{\mathrm{a}}$ & 0.413 & 0.664 \\
\hline
\end{tabular}

Figures bearing common letter(s) in a row as superscript do not differ significantly $(P<0.05)$.

\section{Determination of fish growth and yield}

Fish growth was monitored by weighing at least $10 \%$ of the individual species caught from each pond using a cast net, and sampled fishes were released into the ponds unharmed immediately after sampling. Growth and yield of fishes were calculated after Brett and Groves (1979) as follows:

Initial weight $(\mathrm{g})=$ Weight of fish at stock

Final weight $(\mathrm{g})=$ Weight of fish at harvest

Weight gain $(\mathrm{g})=$ Mean final weight $(\mathrm{g})$ - Mean initial weight $(\mathrm{g})$ $\left(\mathrm{t}_{2}-\mathrm{t}_{1}\right)$

Specific Growth Rate: SGR $\left(\%, b^{-1}\right)=\left[\left(\operatorname{Ln~W}_{2}-\mathrm{Ln} \mathrm{W}_{1}\right) \times 100\right] /$

Where, $\mathrm{W}_{1}$ and $\mathrm{W}_{2}$ are the mean start and end weight $\left(\mathrm{g} \mathrm{fish}^{-1}\right)$ and $\mathrm{t}_{1}$ and $\mathrm{t}_{2}$ (days) are the start and end of the period.
Survival rate $(\%)=($ Number of fish harvested/Number of fish stocked) $\times 100$

Fish yield $\left(\mathrm{kg} \mathrm{ha}^{-1}\right)=$ Fish biomass at harvest - Fish biomass at stock

\section{Economics of Carp Polyculture}

Simple cost-benefit analysis was done to explore the economics of carp polyculture in ponds under different treatments. At the end of the study, all the fishes were sold in a local market. The prices of inputs and fish corresponded to the market prices in Rajshahi, Bangladesh in 2012 and were expressed in Bangladesh currency (Taka) as BDT (1 US $\$=80 \mathrm{BDT}$ ). Data on both fixed and variable costs were recorded to determine the total cost (BDT/ha). Total return determined from the market price of fish sale was expressed as BDT/ha. Net benefit and cost benefit ratio (CBR) were calculated as follows: 


$$
\mathrm{R}=\mathrm{I}-(\mathrm{Fc}+\mathrm{Vc}+\mathrm{Ii})
$$

Where, $\mathrm{R}$ refers to net benefit; I, total income from fish sold; Fc for fixed costs, Vc for variable costs and Ii for interests on input costs.

\section{Statistical Analysis}

$$
\text { Cost }- \text { Benefit Ratio }(C B R)=\frac{\text { Net benefit }}{\text { TotalInvestment }}
$$

Before analysis, the normality of data were verified and then analyzed by one-way ANOVA using SPSS software version 16). Different treatments were compared. The mean values were also compared by Duncan Multiple Range Test (DMRT) after Gomez and Gomez (1984) at 5\% level of significance. All data were expressed as mean \pm standard error (S.E.).

\section{Results}

\section{Water quality}

The ANOVA and Duncan's test showed that there was no significant $(\mathrm{P}<0.05)$ difference of mean value of water quality parameters among the treatments (Table 3) (Figure 1). Mean value of water temperature $\left({ }^{\circ} \mathrm{C}\right)$, dissolved oxygen $\left(\mathrm{mgL}^{-1}\right)$, transparency $(\mathrm{cm}), \mathrm{pH}$ and total alkalinity $\left(\mathrm{mgL}^{-1}\right)$ varied from $27.19 \pm 1.00\left(\mathrm{~T}_{3}\right)$ to $27.60 \pm 0.99\left(\mathrm{~T}_{1}\right), 6.71 \pm 0.24\left(\mathrm{~T}_{3}\right)$ to $6.76 \pm 0.23\left(\mathrm{~T}_{1}\right), 28.57 \pm 0.55\left(\mathrm{~T}_{3}\right)$ to $28.81 \pm 0.45\left(\mathrm{~T}_{1}\right), 7.10 \pm 0.08\left(\mathrm{~T}_{2}\right)$ to $7.19 \pm 0.07\left(\mathrm{~T}_{3}\right)$ and $60.24 \pm 1.87$ $\left(\mathrm{T}_{2}\right)$ to $61.43 \pm 1.76 \mathrm{mgL}^{-1}\left(\mathrm{~T}_{1}\right)$, respectively.

\begin{tabular}{|c|c|c|c|c|c|}
\hline Species & Treatments & $\begin{array}{l}\text { SGR } \\
\left(\%, \text { bwd }^{-1}\right)\end{array}$ & Weight Gain (g) & Final Weight (g) & $\begin{array}{l}\text { Survival Rate } \\
\text { (\%) }\end{array}$ \\
\hline \multirow[t]{3}{*}{ Labeorohita } & $T_{1}$ & $0.88 \pm 0.0 \mathrm{I}^{\mathrm{a}}$ & $66.67 \pm 0.96^{\mathrm{a}}$ & $500.00 \pm 5.7^{\mathrm{a}}$ & $85.50 \pm 0.87^{\mathrm{a}}$ \\
\hline & $\mathrm{T}_{2}$ & $0.85 \pm 0.02^{\mathrm{a}}$ & $61.67 \pm 2.55^{\mathrm{a}}$ & $470.67 \pm 15.26^{\mathrm{a}}$ & $86.50 \pm 0.29^{a}$ \\
\hline & $\mathrm{T}_{3}$ & $0.85 \pm 0.02^{\mathrm{a}}$ & $65.00 \pm 2.93^{\mathrm{a}}$ & $490.00 \pm 17.56^{\mathrm{a}}$ & $85.33 \pm 10.44^{a}$ \\
\hline$F$ value & & 1.271 & 1.217 & 1.217 & 1.162 \\
\hline$P$ value & & 0.347 & 0.360 & 0.360 & 0.374 \\
\hline \multirow[t]{3}{*}{ Catlacatla } & $\mathrm{T}_{1}$ & $0.94 \pm 0.0 \mathrm{I}^{\mathrm{a}}$ & $75.83 \pm 2.2 \mathrm{I}^{\mathrm{a}}$ & $555.00 \pm 13 .^{a}$ & $86.33 \pm 0.44^{a}$ \\
\hline & $\mathrm{T}_{2}$ & $0.92 \pm 0.02^{\mathrm{a}}$ & $73.33 \pm 2.4 I^{\mathrm{a}}$ & $540.00 \pm 14.43^{\mathrm{a}}$ & $87.17 \pm 0.44^{a}$ \\
\hline & $\mathrm{T}_{3}$ & $0.90 \pm 0.02^{\mathrm{a}}$ & $70.00 \pm 2.55^{\mathrm{a}}$ & $490.00 \pm 17.56^{a}$ & $86.50 \pm 0.29^{a}$ \\
\hline$F$ value & & 1.527 & 1.500 & 1.500 & 1.235 \\
\hline$P$ value & & 0.291 & 0.296 & 0.296 & 0.355 \\
\hline \multirow[t]{3}{*}{ Hypopthalmichthysmolitrix } & $T_{1}$ & $1.09 \pm 0.02^{\mathrm{a}}$ & $105.00 \pm 4.19^{a}$ & $730.00 \pm 25 .^{a}$ & $85.33 \pm 0.60^{\mathrm{a}}$ \\
\hline & $\mathrm{T}_{2}$ & $1.07 \pm 0.02^{\mathrm{a}}$ & $102.50 \pm 3.63^{\mathrm{a}}$ & $715.00 \pm 21.79^{a}$ & $86.67 \pm 0.93^{\mathrm{a}}$ \\
\hline & $\mathrm{T}_{3}$ & $1.04 \pm 0.03^{\mathrm{a}}$ & $95.83 \pm 5.20^{\mathrm{a}}$ & $675.00 \pm 31.23^{\mathrm{a}}$ & $86.83 \pm 0.67^{a}$ \\
\hline$F$ value & & 1.164 & 1.164 & 1.164 & 1.217 \\
\hline$P$ value & & 0.374 & 0.374 & 0.374 & 0.360 \\
\hline \multirow[t]{3}{*}{ Aristichthisnobilis } & $T_{1}$ & $1.11 \pm 0.02^{\mathrm{a}}$ & ||$|.67 \pm 4.4|^{\mathrm{a}}$ & $770.00 \pm 26.46^{a}$ & $85.67 \pm 0.44^{a}$ \\
\hline & $\mathrm{T}_{2}$ & $1.09 \pm 0.02^{\mathrm{a}}$ & $106.67 \pm 3.85^{\mathrm{a}}$ & $740.00 \pm 23.09^{a}$ & $87.17 \pm 0.73^{\mathrm{a}}$ \\
\hline & $\mathrm{T}_{3}$ & $\mathrm{I} .07 \pm 0.0 \mathrm{I}^{\mathrm{a}}$ & $102.50 \pm 2.10^{\mathrm{a}}$ & $715.00 \pm 12.58^{a}$ & $85.50 \pm 0.29^{a}$ \\
\hline$F$ value & & 1.644 & 1.635 & 1.635 & 3.138 \\
\hline$P$ value & & 0.274 & 0.271 & 0.271 & 0.117 \\
\hline Cyprinuscarpio & $T_{1}$ & $1.08 \pm 0.03^{\mathrm{a}}$ & $105.00 \pm 6.74^{\mathrm{a}}$ & $730.00 \pm 40.42^{\mathrm{a}}$ & $87.17 \pm 0.88^{a}$ \\
\hline$F$ value & & 12.437 & 16.842 & 16.305 & 0.530 \\
\hline$P$ value & & 0.007 & 0.003 & 0.001 & 0.615 \\
\hline Cirrhinusmrigala & $\mathrm{T}_{2}$ & $0.94 \pm 0.02^{b}$ & $75.83 \pm 3.76^{b}$ & $555.00 \pm 22.55^{\mathrm{b}}$ & $86.83 \pm 0.17^{\mathrm{a}}$ \\
\hline$F$ value & & 9.133 & 11.412 & 23.698 & 0.526 \\
\hline$P$ value & & 0.005 & 0.003 & 0.002 & 0.620 \\
\hline
\end{tabular}

Table 3 Growth and yield of fishes under different treatments. 


\begin{tabular}{|c|c|c|c|c|c|}
\hline Species & Treatments & $\begin{array}{l}\text { SGR } \\
\left(\%, \text { bwd }^{-1}\right)\end{array}$ & Weight Gain (g) & Final Weight (g) & $\begin{array}{l}\text { Survival Rate } \\
\text { (\%) }\end{array}$ \\
\hline Labeocalbasu & $\mathrm{T}_{3}$ & $0.87 \pm 0.02^{\mathrm{b}}$ & $65.83 \pm 2.2 \mathrm{I}^{\mathrm{b}}$ & $495.00 \pm 13.23^{b}$ & $87.67 \pm 0.44^{a}$ \\
\hline$F$ value & & 22.312 & 9.842 & 18.218 & 0.528 \\
\hline$P$ value & & 0.003 & 0.002 & 0.001 & 0.610 \\
\hline \multirow[t]{3}{*}{ All species } & $\mathrm{T}_{1}$ & $1.02 \pm 0.02^{\mathrm{a}}$ & $92.83 \pm 3.70^{\mathrm{a}}$ & $657.00 \pm 22.2 I^{\mathrm{a}}$ & $86.00 \pm 0.65^{c}$ \\
\hline & $\mathrm{T}_{2}$ & $0.97 \pm 0.02^{b}$ & $84.00 \pm 3.24^{b}$ & $604.13 \pm 19.35^{b}$ & $86.87 \pm 0.5 I^{b}$ \\
\hline & $\mathrm{T}_{3}$ & $0.95 \pm 0.02^{b}$ & $79.83 \pm 2.99^{b}$ & $573.00 \pm 18.42^{b}$ & $88.37 \pm 2.42^{\mathrm{a}}$ \\
\hline$F$ value & & 7.069 & 6.230 & 9.105 & 1.188 \\
\hline$P$ value & & 0.002 & 0.187 & 0.186 & 0.435 \\
\hline
\end{tabular}

Figures bearing common letter(s) in a column as superscript do not differ significantly $(P<0.05)$.
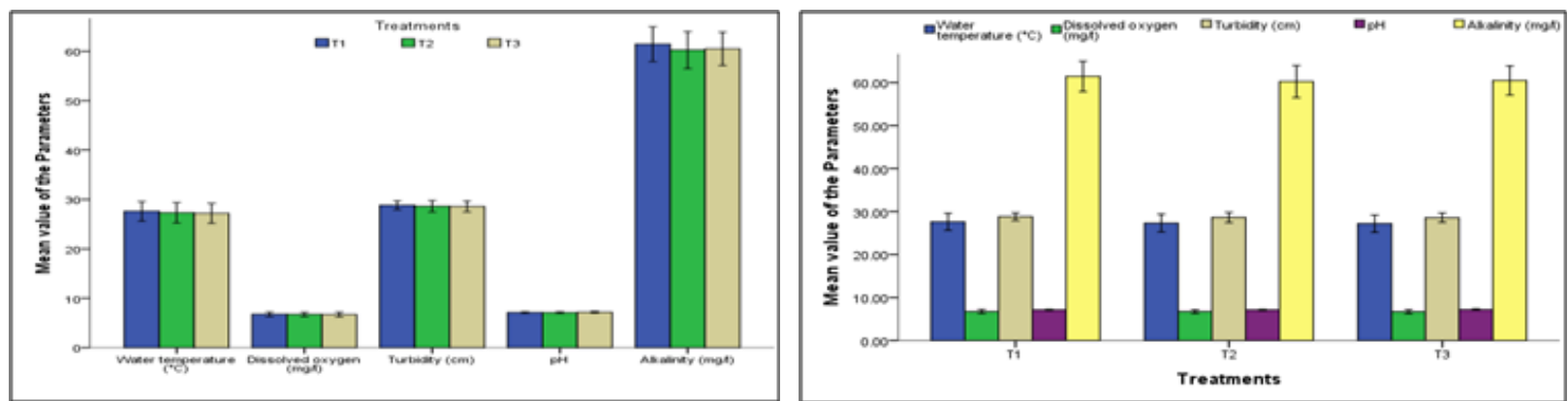

Figure I Variation in the mean value of the water quality parameters $a_{1}$ : treatment-based presentation of water quality parameters, and $b_{1}$ : treatment-based comparison of water quality parameters.

\section{Fish growth}

Results showed no significant $(\mathrm{P}<0.05)$ differences in the mean value of SGR, weight gain and final weight for all fish species except C. carpio $\left(\mathrm{T}_{1}\right)$, C. mrigala $\left(\mathrm{T}_{2}\right)$, and $L$. calbasu $\left(\mathrm{T}_{3}\right)$. Duncan's test revealed that mean value of SGR, final weight and weight gain in treatment $\mathrm{T}_{1}$ (with $C$. carpio as bottom feeder) was significantly $(\mathrm{P}<0.05)$ higher compared to $\mathrm{T}_{2}$ and $\mathrm{T}_{2}$, where $C$ mrigala and $L$ calbasu were stocked as bottom feeder, respectively. The examined treatments were statistically similar in the estimation of survival rates for all fish species under three treatments (Table 4).

Table 4 Fish yield ( $\mathrm{kg} / \mathrm{ha} / 6$ months) under the treatments.

\begin{tabular}{llllll}
\hline Species & Treatments & & & & \\
& $\mathbf{T}_{1}$ & $\mathbf{T}_{2}$ & $\mathbf{T}_{3}$ & & \\
\hline L. rohita & $675.69 \pm 8.70^{\mathrm{a}}$ & $632.55 \pm 27.82^{\mathrm{a}}$ & $657.83 \pm 32.20^{\mathrm{a}}$ & 0.747 & 0.513 \\
C. catla & $291.16 \pm 9.87^{\mathrm{a}}$ & $284.11 \pm 7.92^{\mathrm{a}}$ & $269.27 \pm 10.66^{\mathrm{a}}$ & 1.368 & 0.324 \\
H. molitrix & $1062.40 \pm 44.19^{\mathrm{a}}$ & $1052.99 \pm 35.59^{\mathrm{a}}$ & $986.01 \pm 48.44^{\mathrm{a}}$ & 0.935 & 0.443 \\
A. nobilis & $425.22 \pm 15.85^{\mathrm{a}}$ & $413.23 \pm 13.24^{\mathrm{a}}$ & $389.63 \pm 7.93^{\mathrm{a}}$ & 2.011 & 0.215 \\
C. carpio & $1083.93 \pm 61.10^{\mathrm{a}}$ & & & 24.960 & 0.001 \\
C.mrigala & & $780.78 \pm 39.56^{\mathrm{b}}$ & & 22.621 & 0.001 \\
L. calbasu & & & $684.04 \pm 19.73^{\mathrm{b}}$ & 20.638 & 0.001 \\
All species & $3538.41 \pm 64.17^{\mathrm{a}}$ & $3163.66 \pm 22.12^{\mathrm{b}}$ & $2986.77 \pm 94.89^{\mathrm{b}}$ & 17.484 & 0.003 \\
\hline
\end{tabular}

Figures bearing common letter(s) in a row as superscript do not differ significantly $(P<0.05)$.

\section{Fish yield}

The present study revealed significant $(\mathrm{P}<0.05)$ difference in the yield under different treatments with highest in $T_{1}$ and lowest in $T_{3}$.
The study also revealed that the mean value of yield for $C$. carpio $\left(\mathrm{T}_{1}\right)$, C. mrigala $\left(\mathrm{T}_{2}\right)$ and L. calbasu $\left(\mathrm{T}_{3}\right)$ were significantly different, whereas mean value of yield of other fish species were statistically similar (Table 5 \& Figure 2). 
Table 5 Economics of carp polyculture under different treatments.

\begin{tabular}{|c|c|c|c|c|c|}
\hline \multirow{2}{*}{$\begin{array}{l}\text { Treatments } \\
\text { Parameters }\end{array}$} & \multicolumn{3}{|c|}{ Treatments (mean value in BDT/ha/6 months) } & \multirow{2}{*}{$\begin{array}{l}\text { F } \\
\text { Value }\end{array}$} & \multirow[b]{2}{*}{$P$ value } \\
\hline & $\mathbf{T}_{1}$ & $\mathbf{T}_{2}$ & $\mathbf{T}_{3}$ & & \\
\hline \multicolumn{6}{|l|}{ Variable Costs } \\
\hline Pond preparation* & $9000.00 \pm 0.00^{\mathrm{a}}$ & $9000.00 \pm 0.00^{\mathrm{a}}$ & $9000.00 \pm 0.00^{\mathrm{a}}$ & - & - \\
\hline Fertilizer & $17500.00 \pm 0.00^{\mathrm{a}}$ & $17500.00 \pm 0.00^{\mathrm{a}}$ & $17500.00 \pm 0.00^{\mathrm{a}}$ & - & - \\
\hline Fish seed & $90400 \pm 11.25^{c}$ & $95000.00 \pm 8.25^{\mathrm{b}}$ & $96250 \pm 14.23^{\mathrm{a}}$ & - & - \\
\hline Feed & $110150.00 \pm 563.00^{c}$ & $\mathrm{I} 12330.00 \pm 0.00^{\mathrm{b}}$ & $1157 \mid 5 \pm 0.00^{\mathrm{a}}$ & 239.958 & 0.000 \\
\hline Harvesting cost & $2000.00 \pm 0.00^{\mathrm{a}}$ & $2000.00 \pm 0.00^{\mathrm{a}}$ & $2000.00 \pm 0.00^{\mathrm{a}}$ & - & - \\
\hline \multicolumn{6}{|l|}{ Fixed Costs } \\
\hline Pond Rental & $1500.00 \pm 0.00^{\mathrm{a}}$ & $1500.00 \pm 0.00^{\mathrm{a}}$ & $1500.00 \pm 0.00^{\mathrm{a}}$ & - & - \\
\hline Total cost & $230550.00 \pm 0.00^{c}$ & $237330.00 \pm 944.39^{b}$ & $241965.00 \pm 0.00^{\mathrm{a}}$ & 678.183 & 0.000 \\
\hline Total return & $530252.32 \pm 8232.07^{\mathrm{a}}$ & $478623.0 \mathrm{I} \pm 3274.96^{\mathrm{b}}$ & $466219.40 \pm|24| 4.15^{c}$ & 43.874 & 0,005 \\
\hline Net benefit & $299702.32 \pm 8232.06^{\mathrm{a}}$ & $24 I 293.0 I \pm 3274.96^{b}$ & $224254.40 \pm 10993.24^{c}$ & 23.563 & 0.001 \\
\hline $\begin{array}{l}\text { Cost Benefit Ratio } \\
\text { (CBR) }\end{array}$ & $1.30 \pm 0.036^{\mathrm{a}}$ & $1.02 \pm 0.114^{b}$ & $0.93 \pm 0.040^{c}$ & 37.234 & 0.000 \\
\hline
\end{tabular}

Figures bearing common letter(s) in a row as superscript do not differ significantly $(\mathrm{P}<0.05)$

Note: Currency is given in Bangladeshi Taka (BDT); (80 BDT = I USD, 20I2)

* includes lime, ash and labor cost

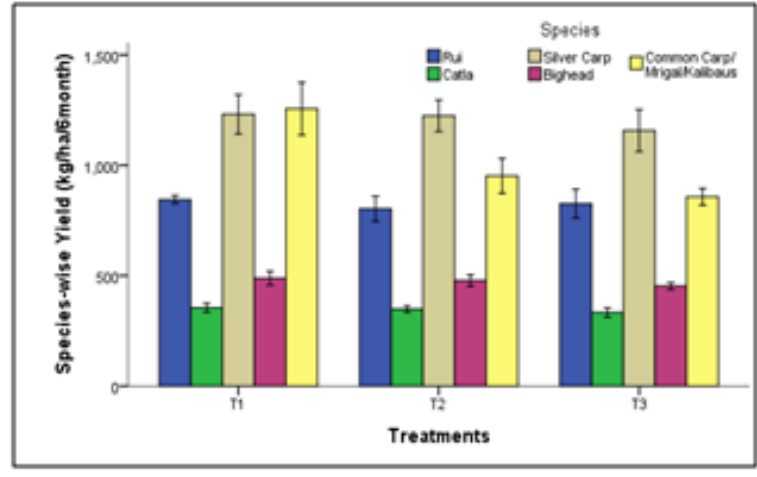

a1

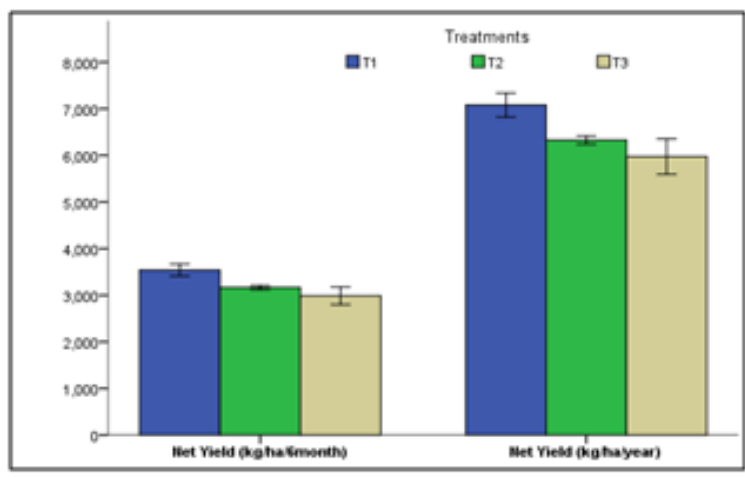

$b_{1}$

Figure $2 \mathrm{a}_{1}$ : individual fish yield (kg/ha/6 months) and $\mathrm{b}_{1}$ : treatment based yield for six months and one year under different treatments.

\section{Discussion}

\section{Water quality}

Lower temperature recorded in the later stage of the study might be gradual approach to the winter that might have impact on the seasonal variation of the water quality. ${ }^{7}$ Lower value of water transparency found in all treatments might be due to higher clay turbidity caused by heavy rainfall in monsoon. Periodic application of ash minimized high turbidity during the high rainy season. Hossain ${ }^{4}$ reported high turbidity during monsoon and followed ash treatment to maintain suitable water turbidity. Saran \& Rathore ${ }^{8,9}$ stated lower transparency due to rich phytoplankton density and higher budgets of suspended and particulate matter. Boyd ${ }^{10}$ recommended 30 to $40 \mathrm{~cm}$ transparency appropriate for fish culture. Similar to the current results, Dewan \& Swingle ${ }^{11,12}$ recorded mean $\mathrm{pH}$ value of water from $6.60-8.60$ and
6.5 to 9 , respectively. Boyd ${ }^{10}$ suggested over $20 \mathrm{ppm}$, and Michael \& Verma ${ }^{13,14}$ suggested over $40 \mathrm{ppm}$ total alkalinity for productive pond that aligned with present results. However, Asadujjaman and Hossain ${ }^{4}$ recorded relatively higher total alkalinity (113.28 to $\left.114.36 \mathrm{mgL}^{-1}\right)$ in feed and weed based pond polyculture that might be due to low dissolved oxygen and more production of free $\mathrm{CO}_{2}$ that enhanced by increasing fish biomass.

However, above findings indicated that the mean value of the water quality parameters in the present study were within the suitable range for aquaculture. The findings from resent studies also supported the above statement. Talukder et al. ${ }^{2}$ found water temperature 26.57 to $26.68^{\circ} \mathrm{C}$, dissolved oxygen 6.81 to $6.86 \mathrm{mgL}^{-1}$, water transparency 29.90 to $30.17 \mathrm{~cm}, \mathrm{pH} 6.88$ to 6.96 and alkalinity 51.29 to $52.26 \mathrm{mg}$ $\mathrm{L}^{-1}$ in carp polyculture ponds. Asaduzzaman et al. ${ }^{15}$ reported water temperature, dissolved oxygen, transparency, $\mathrm{pH}$ and total alkalinity 
as 27.57 to $28.13^{\circ} \mathrm{C}, 6.51$ to $6.73 \mathrm{mgL}^{-1}, 32.83$ to $32.28 \mathrm{~cm}, 7.38$ to 7.18 , $61 ; 51$ to $63.17 \mathrm{mgL}^{-1}$. Ahmad et al. reported temperature from 27.08 to $28.66^{\circ} \mathrm{C}$, DO from 5.15 to $5.91 \mathrm{mgL}^{-1}$, transparency from 18.17 to $25.50 \mathrm{~cm}$ and $\mathrm{pH}$ from 8.04 to 8.23 in polyculture pond. The mean water temperature, $\mathrm{pH}, \mathrm{DO}, \mathrm{CO}_{2}$ and total alkalinity was recorded as 19.6 to $32^{\circ} \mathrm{C}, 6.6$ to $8.0,1.1$ to $4.9 \mathrm{mgL}^{-1}, 3.5$ to $4.0 \mathrm{mgL}^{-1}$ and 92.0 to $167 \mathrm{mgL}^{-1}$, respectively in polyculture pond. ${ }^{16}$ Hossain et al. ${ }^{17}$ recorded dissolved oxygen ranging from 5.33 to $5.51 \mathrm{mgL}^{-1}$.

\section{Fish growth}

Significant $(\mathrm{P}<0.05)$ differences in mean values of fish growth parameters were found among the treatments (Table 4). However, variations in growth might be due to the different combination of fish species under treatments.

Comparatively higher mean value of SGR, final weight, weight gain indicated the positive influence of $C$. carpio as bottom feeder on overall growth parameters compared to $C$ mrigala and $L$ calbasu in carp polyculture. Rahman et al. ${ }^{18}$ recorded mean SGR of rohu, catla and mrigal as $1.12,1.09$ and 1.13 to $1.13,1.12$ and 1.14 respectively in different treatments under pond polyculture system. Majhi et al. ${ }^{19}$ recorded SGR value of carp as $1.65 \%$ in fish pond. Hossain ${ }^{4}$ found weight gain of L. rohita, C. catla, C. mrigala, H. molitrix, A. nobilisand C. carpio as $125.7,170.2,120.8,400.2,402,400 \mathrm{~g}$, respectively with stocking weight of 7.5 to $10.0 \mathrm{~g}$ in polyculture under Barind area which were lower than the findings from present study. Comparatively higher mean monthly weight gain (g/month) was observed at mid time of the study might be due to influence of air temperature on water temperature resulting fast metabolic activity and thereby higher weight gain of fishes at the mid-stage of the experiment. Boyd $\mathrm{d}^{20}$ expressed similar opinion while working on pond carp polyculture.

No significant $(\mathrm{P}<0.05)$ variations in survival rate $(\%)$ under different treatments possibly due to similar stocking weight and stocking density of fishes including similar feed and management of all ponds. Talukder et al. ${ }^{2}$ reported similar survival rates $(83.17 \pm 0.58$ $84.13 \pm 0.58,85.33 \pm 0.58,84.13 \pm 1.00,85.33 \pm 0.58,84.42 \pm 0.66 \%$ ) for L. rohita, C. catla, C. mrigala, $H$. molitrix and A. nobilis, respectively in carp polyculture ponds. Asadujjaman and Hossain ${ }^{15}$ recorded similar range of survival rate (\%) of L. rohita, C. catla, C. mrigala, $H$. molitrix and C. idella. Kabir \& Talukdar et al. ${ }^{3,21}$ recorded survival rate of C. carpio from 83.2 to 86 and $82 \%$, respectively in carp polyculture system. Roy et al. ${ }^{22}$ reported survival rate (\%) of grass carp, rohu, catla and mrigal $76.6 \%, 87.8 \%, 84.0 \%$ and $88.6 \%$, respectfully, which are likely findings of present study.

Azad et al. ${ }^{23}$ reported weight gain of $H$. molitrix as $72.87 \mathrm{~g}$ and C. mrigala as $70.42 \mathrm{~g}$ in carp polyculture ponds which were lower than the present findings. Kabir et al. ${ }^{3}$ found final weight ( $\mathrm{g} / 6$ months) of H. molitrix, C. mrigala and C. carpio as 300,210 and $211.20 \mathrm{~g}$, respectively which were lower than the present findings. Higher final weight ( $\mathrm{g} / 6$ months) achieved in the present study might be due to optimum species composition, larger stocking weight and better management of water quality, proper utilization of both natural and supplementary feed.

\section{Fish yield}

Yield significantly $(\mathrm{P}<0.05)$ varied among all three treatments. The study revealed that the combined yield of $L$. rohita, C. catla, $H$. molitrix and A. nobilis under three treatments were not significantly varied; but yield significant $(\mathrm{P}<0.05)$ varied in case of three different bottom feeders e.g. C. Carpio: $1083.93 \pm 61.09 \mathrm{~kg} / \mathrm{ha} / 6$ months $\left(\mathrm{T}_{1}\right)$, C. mrigala: $780.78 \pm 39.562 \mathrm{~kg} / \mathrm{ha} / 6$ months $\left(\mathrm{T}_{2}\right)$, and $L$. calbasu: $684.04 \pm 19.733 \mathrm{~kg} / \mathrm{ha} / 6$ months $\left(\mathrm{T}_{3}\right)$, respectively. That might be due to difference in first growing nature of three bottom feeders as well as effects of combination of other fish species. Yield of C. carpio was found significantly high compared to other two bottom feeders which finally contributed to overall variation in net yield.

Siddiquei ${ }^{24}$ reported that the gross fish production of $40.4 \mathrm{~kg} / \mathrm{dec} /$ $\mathrm{yr}$ from mixed culture which is a bit higher than the present findings. Noman et al. ${ }^{25}$ reported that comparatively higher yield and net benefit were observed when $C$. carpio was used in carp polyculture. Net yield of the present study was higher in $T_{1}$, compared to $T_{2}$ and $T_{3}$ might be due to first growing nature of $C$. carpio and larger stocking weight with better pond management and suitable range of water quality parameters. Asadujjaman \& Hossain ${ }^{15}$ recorded total yield of $4,403.51 \mathrm{~kg} / \mathrm{ha} / 6$ months with conventional feed applied and lower production of $2,541.00 \mathrm{~kg} / \mathrm{ha} / 6$ months where only banana leaf was supplied. Miajae $^{26}$ reported the total production of fish from 2,934 to $3,318 \mathrm{~kg} / \mathrm{ha} / 4$ months in polyculture of Indian major carps which was similar to the findings from present study. Azim et al. ${ }^{27}$ recorded total fish yield of $2,020 \mathrm{~kg} / \mathrm{ha} / 4$ months in pond which was lower than the findings from the present study possibly due to higher stocking weight in present study. Such variations in growth and yield among the treatments were the usual phenomenon of fish growth form which was strongly supported by Grover et al. ${ }^{28}$

\section{Economics}

Economic analysis of current study showed significant $(\mathrm{P}<0.05)$ variations in total cost, return, net benefit and CBR among treatments (Table 5) (Figure 3). Comparatively higher cost was involved in treatment $\mathrm{T}_{3}$ might be due to the higher fish seed cost for $L$. calbasu compared to C. carpio $\left(\mathrm{T}_{1}\right)$ and C. mrigala $\left(\mathrm{T}_{2}\right)$.

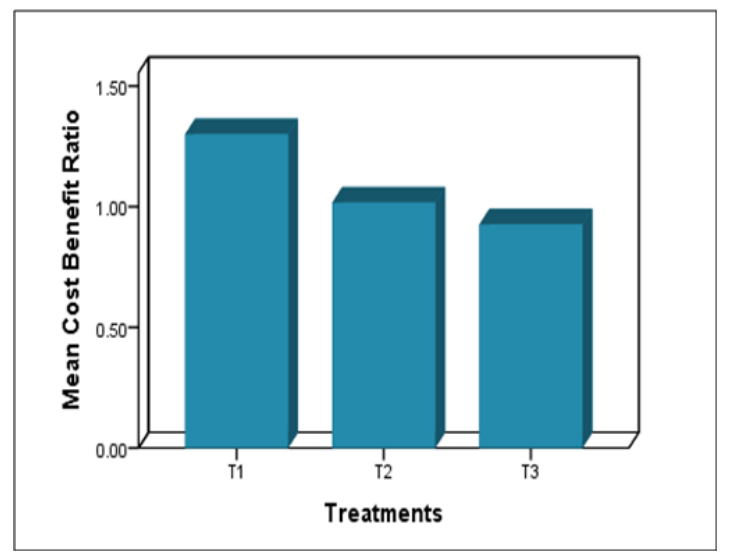

Figure 3 Variation in the mean values of CBR under different treatments.

Talukder et al. $^{2}$ recorded total cost and net benefits as $253,768.00 \pm 5146.04$ and $337,629.45 \pm 7295.36 \mathrm{BDT} / \mathrm{ha} / 6$ months, respectively and cost benefit ratio as 1.33 . Asadujjaman \& Hossain ${ }^{15}$ recorded $123,430.50 \pm 0.00$ to $235,930.50 \pm 0.00 \mathrm{BDT} / \mathrm{ha} / 6$ months; net benefit as $111,639.90 \pm 2056.87$ to $206,744.85 \pm 3221.73 \mathrm{BDT} / \mathrm{ha} / 6$ months; and cost benefit ratio as $0.77 \pm 0.02$ to $1.67 \pm 0.18$, respectively in carp polyculture system. Khan et al. ${ }^{29}$ reported CBR value of 1.22 in pond polyculture system; and Abou et al. ${ }^{30}$ found CBR as 1.3 in carp polyculture system which was similar to the present findings. 
Overall findings from the current study revealed that treatment $T$ with $C$. carpio as bottom feeder performed better in terms of total cost, net benefit and CBR compared to treatment $\mathrm{T}_{2}$ and $\mathrm{T}_{3}$ stocked with $C$. mrigala and L. calbasu, respectively. Milstein et. al. ${ }^{6}$ certify $C$. carpio as a first growing and high tolerant to environmental hazards.

According to Jain C. carpio has the ability to survive under various climatic conditions and found to be the most suitable for many fish farming systems. Da Silva et al. concluded that C. carpio has the potential to improve conditions in pond bottom soil, as a result soil perturbation increases the oxygen transfer to the soil, decreases the concentration of toxic compounds and enables more efficient food web recycling and nutrient release. ${ }^{31-38}$

\section{Conclusion and Recommendation}

Considering the water quality, growth and yield of fish and economic viability of carp polyculture in pond under three treatments, treatment it can be concluded that stocking of $C$. carpio as bottom dwelling species can be a suitable option for carp polyculture in ponds under drought prone Barind area. One of the major limitations of this study was to use equal stocking density of all three bottom dwelling species. Therefore, it is necessary to see the effect of different stocking density of C. carpio as bottom dwelling species in carp polyculture as further step.

\section{Acknowledgment}

None.

\section{Conflict of Interest}

None.

\section{References}

1. DoF (Department of Fisheries). National Fish Week 2017 Compendium (in Bengali). Department of Fisheries, Ministry of Fisheries and Livestock, Bangladesh. 2017; 160 p.

2. Talukder MGS, Mohsin ABM, Hossain MA, et al. Optimization of stocking weight in carp polyculture ponds under drought prone Barind area of Bangladesh. Journal of Fisheries. 2017;5:3.

3. Kabir ANMA, Hossain MA, Rahman MS. Use of duckweed as feed for fishes in polyculture. Journal of Agriculture and Rural Development. 2009;7(1-2):157-160.

4. Hossain MA. Effect of fertilization techniques on fish growth in ponds under red soil zone of northern Bangladesh. Journal of Progressive Science and Tech. 2011;9(2):192-196.

5. Mishra AK Singh VP. A review of drought concepts. Journal of Hydrology. 2010;391(1-2):202-216.

6. Milstein A, Wahab MA, Rahman MM. Environmental effects of common carp Cyprinus carpio (L.) and mrigal Cirrhinus mrigala (Hamilton) as bottom feeders in major Indian carp polycultures. Aquaculture Research. 2002;33(14):1103-1117.

7. Halwart M Gupta MV. Culture of fish in rice fields. FAO and the World Fish Center. 2004; 83 p.

8. Saran WM, Adoni AD. Studies on seasonal variation on $\mathrm{pH}$ and dissolved oxygen contents in Sagarlake. Acta Botanica India. 1982;10:324-326.

9. Rai JPN, Rathore VS. Pollution of Nainital Lake water and its management. In: Ecology and pollution of Indian Lakes and reservoirs, Ash. Pub House, India. 1993. p. 1-247.
10. Boyd CE . Water quality management of pond fish culture. Elsevier Science Publications Company, Amsterdam-Oxford, USA. 1982. 318 p.

11. Dewan SM, Wahab MA, Beveridge MCM, et al. Food selection, electivity and dietary overlap among planktivorous Chinese and Indian major carp fry and fingerlings grown in extensively managed, rain-fed ponds in Bangladesh. Aquaculture and Fisheries Management. 1991;12 (3):227-294

12. Swingle HS. Standardization of chemical analysis from water and pond muds. FAO, Fish Rep. 1967; 494, p. 397-421.

13. Michael R. Seasonal trends in physico-chemical factors and plankton in a fresh water fish pond and their role in fish culture. Hydrobiol. 1968;33:144-158.

14. Verma NM. Hydro-biological study of a tropical impoundment, Gualior, India, with special reference to the breeding of Indian carps. Hydrobiology. 1969;34(3-4):358-368.

15. Asadijjaman M, Hossain MA. Fish growth, yield and economics of conventional feed and weed based polyculture in ponds. Journal of Fisheries. 2016;4(1):353-360.

16. Mamun AA, Mahmud AI. Study on growth performence and production of juvenile Indian major carp (Catla catla, Labeo rohita and Cirrhinus cirrhosus) and their hybrids. Journal of Fisheries and Aquatic Science. 2014;9(3):92-108.

17. Asadujjaman M, Azad MAK, Ali MR, et al. Optimization of stocking density for Azolla based carp polyculture pond. International Journal of Fisheries and Aquaculture Studies. 2016;4(4):273-279.

18. Rahman MA, Hossain MK, Azad MAK. Culture potential of Thai Sharpunti, Barbodesgonionotus (Bleeker) with major carps in seasonal ponds. Pakistan Journal of Biological Science. 2006;9(10):1891-1897.

19. Majhi SK, Das A, Mandal BK. Growth Performance and Production of Organically Cultured Grass Carp Ctenopharyngodonidella (Val.) Under Mid-Hill Conditions of Meghalaya; North Eastern India. Turkish Journal of Fisheries and Aquatic Sciences. 2006;6:105-108.

20. Boyd CE. Water quality for fish pond. Aquaculture Research and Development Series No. 43.Aburn University, Alabama, USA. 1998; p. 37.

21. Talukdar MZH, Shahjahan, Rahman MS. Suitability of duckweed (Lemna minor) as feed for fish in polyculture system. International Journal of Agricultural Innovation \& Technology. 2012;2(1):42-46.

22. Roy NC, Kohinoor AHM, Wahab MA, et al. Evaluation of performance of carp-SIS polyculture technology in the rural farmers' pond.Asian Fisheries Science. 2002;15(2002):43-52.

23. Azad MAK, Rahman MR, Rahman Z, et al. Polyculture of carp, tilapia and pangas using low cost inputs. Pakistan Journal of Biological Science. 2004;7(11):1918-1926.

24. Siddiquei IR. Notun Niyame Maccherchas O UtpadonPadhoti. Salahuddin Bai Ghar, Dhaka. 2001; p. 80.

25. Noman M, Ashraf M, Abbas S, et al. Growth performance of common carp (Cyprinus carpio) in response to organic fertilizers and supplementary feed. Greener Journal of Agricultural Sciences. 2011;1(2):032-040.

26. Miajae MAH. Effect of supplementary feed on the growth of Indian major carps with Thai sarputi in polyculture. Bangladesh Journal of Training and Development. 1999;13:117-124.

27. Azim ME, Wahab MA. Development of a duckweed-fed carp polyculture system in Bangladesh. Aquaculture. 2003;18(1-4): 425-438.

28. Grover JH, Islam MA, Shah WA, et al. Training manual for extension personnel on low cost environment friendly sustainable aquaculture practices. ICLARM, India. 2000; p. 101. 
29. Khan S, Hossain MS, Haque MM. Effects of feeding schedule on growth, production and economics of pangasiid catfish (Pangasiushypophthalmus) and silver carp (Hypophthalmichthysmolitrix) polyculture. Journal of Bangladesh Agricultural University. 2009;7(1): 175-181.

30. Abou Y, Fiogbe ED, Micha J. Effects of stocking density on growth, profitability of farming Nile tilapia, Orechromisniloticus L., fed Azolla diet, in earthen ponds. Aquaculture Research. 2007;38:595-604.

31. Alam MJ, Kohinoor AHM, Islam MS, et al. Polyculture of carps using over-wintered fingerlings under different stocking densities. Bangladesh Journal of Fisheries Research .2002;6(2):117-124.

32. Azim ME, Wahab, MA, Kamal AHM, et al. Feeding relations of silver barb, Barbodesgonionotus (Bleeker) with major Indian and common carp and its effect on fish production in a polyculture system. Journal of the World Aquaculture Society. 2004;35(1):100-108.

33. Boyd CE, Zimmermann S. Grow-out systems-water quality and soil management. Blackwell Science. Oxford, UK.2000; p. 221-238.
34. Brett JR, Groves TDD. Physiological energetics. In: Fish Physiology. vol. VIII, Bioenergetics and Growth, WS Hoar, DJ Randall, JR Brett, editors, Academic Press, USA.1979; p. 280-352.

35. DoF (Department of Fisheries) Fish Fortnight Compendium. Department of Fisheries, Ministry of Fisheries \& Livestock, Government of the People's Republic of Bangladesh, India. 2016;148 p.

36. Gomez KA, Gomez AA. Statistical Procedure for Agricultural Research. 2nd ed, John Wiley \& Sons, USA. 1984. 697 p.

37. Hossain MY. Effects of iso-phosphorus organic and inorganic fertilizer on water quality parameters and biological production. M.S. Thesis, Department of Fisheries Management, BAU, Mymensingh, Bangladesh. 2000. 74 p.

38. Wahab MA, Ahmed ZF, Islam A, et al. Effects of introduction of common carp, Cyprinus carpio on the pond ecology and growth of fish in polyculture. Aquaculture Research. 1995;26(9):619-628. 